\title{
Construction Procedures for Public Goods on Roads of Local Interest in Slovenia
}

\author{
Nataša ŠUMAN, Zlata DOLAČEK-ALDUK, Uroš KLANŠEK
}

\begin{abstract}
This paper deals with the issue of construction procedures for public goods on roads of local interest in Slovenia. The methodological frameworks of construction procedures for investment maintenance works and maintenance works in public interest are proposed for that purpose. A complete flow of activities required for such constructions is presented here, namely from preparation of project documentation through realization and inspection to the final acceptance of executed works. The applicability of the discussed approach is shown on practical examples. The paper is intended to serve as a guide to the local communities in Slovenia as well as an informative material to nearby countries that have similar regulations in considered field. The aim is to improve the local governance related to public goods on road infrastructure as well as to share key information about considered topic with a wider international expert audience for discussion and proposals of improvement.
\end{abstract}

Keywords: construction procedures; local governance; maintenance works; public goods; roads

\section{INTRODUCTION}

Construction and maintenance of public goods often represent challenging tasks for many local communities, especially for smaller ones. Namely, alongside a broad range of duties, municipalities are responsible to manage public goods and are specifically in charge of building and maintaining local roads including other public paths [1]. The services of general economic interest, such as construction works on local roads, provide daily necessary goods to residents in local communities [2] and thus need to be adequately taken into consideration. However, on one side, road construction and maintenance are capital intensive [3] while, investing in road infrastructure and its maintenance may cause significant distress in local selfgovernments [4]. From the viewpoint of construction operations, suitable contracts for maintaining and improvement of road infrastructure should be applied to enable efficient support for its management and maintenance [5] while proper methods for evaluating the road condition should be used to identify necessity for executing maintenance works [6].

Moreover, a long-lasting interest in the provision of public roads under different levels of jurisdictional controls [7] cannot be overlooked. Additionally, property issues related to the field of public goods [8] may appear in cases when the investment maintenance works or the maintenance interventions in public interest should be carried out on local roads. Another problem is that the municipalities can have significantly different professional and administrative capacities [9], which is why some of them cannot fully cope with challenges related to public goods on local roads.

Nevertheless, there are more than $13380 \mathrm{~km}$ of local roads and over $18980 \mathrm{~km}$ of public paths in Slovenia [10] which should be suitably maintained according to the procedures set by current regulations. Sustainable land governance, in terms of public infrastructure, is closely conditioned by adequate performance of mentioned procedures. Therefore, the methodological frameworks of construction procedures for investment maintenance works (IMW) and maintenance works in public interest (MWPI) are proposed in this paper. A complete flow of required activities is intended to provide guidelines to local communities in Slovenia for managing construction procedures of such works, i.e. from preparation of project documentation through realization, to inspection, and final acceptance of built objects. To the best of our knowledge, the addressed methodological frameworks can be also recognized as novelty on a global scale since literature review revealed a considerable lack of published research works in this particular area. Besides, the paper may also be a valuable source of information for some other nearby countries that share similar regulations in the considered field.

This paper initially presents a brief overview on expenditures related to road infrastructure. Thereupon, the legislative basis for public goods in Slovenia as well as the areas and interventions on roads of local interest are introduced. The core of the article exposes the methodological frameworks for IMW and MWPI on local roads and addresses their applicability on several practical examples. Finally, conclusions and recommendations for a future work are given towards the end of the paper.

\section{A BRIEF OVERVIEW ON EXPENDITURES RELATED TO ROAD INFRASTRUCTURE}

National and local governments of countries normally spend significant amount of their budget in building and maintaining the road infrastructure network. How much expenditures each EU country allocates for road infrastructure is demonstrated in the latest CE Delft [11] report from 2016. It states the relevant data for all EU Member States except Cyprus. The report distinguishes between investments and operational and maintenance (O\&M) expenditures. Investments are set as expenditures on the enhancement (i.e. preparation of investment, building new road or expending existing road) and renewal (i.e. major renovations increasing the performance of existing infrastructure assets) of road infrastructure network. O\&M expenditures are associated to 'ordinary' maintenance, i.e. maintenance that cannot be avoided. Maintenance actions normally do not change the performance of infrastructure asset, but simply maintain it in good working order. Operational expenditures are commonly intended to assure that the existing infrastructure can be continuously in suitable use (e.g. lighting).

The report [11] states total investments in road infrastructure carried out by EU countries. Tab. 1 presents the average annual investments in long-term period 19952003, investments in 2013 and ratio of investments in 2013 and long-term average annual investments in Central and 
Eastern European countries (CEEC) and EU27. Note, however, that the data is presented as real investments at euro price levels of 2013 in which VAT payments are not included.

Table 1 Total investments in road infrastructure in CEEC (in 2013) [11]

\begin{tabular}{|c|c|c|c|}
\hline \multirow{2}{*}{ Member State } & $\begin{array}{c}\text { Long-term } \\
\text { average } \\
\text { annual } \\
\text { investments }\end{array}$ & $\begin{array}{c}\text { Investments } \\
\text { in } 2013\end{array}$ & $\begin{array}{c}\text { Ratio of } \\
\text { investments }\end{array}$ \\
\cline { 2 - 4 } & mln euro & mln euro & $\%$ \\
\hline Bulgaria & 273 & 380 & 139 \\
\hline Czech Republic & 1597 & 897 & 56 \\
\hline Estonia & 128 & 120 & 94 \\
\hline Croatia & 718 & 450 & 63 \\
\hline Hungary & 692 & 401 & 58 \\
\hline Latvia & 161 & 150 & 93 \\
\hline Lithuania & 274 & 253 & 92 \\
\hline Poland & 3180 & 2931 & 92 \\
\hline Romania & 2343 & 3061 & 131 \\
\hline Slovakia & 493 & 360 & 73 \\
\hline Slovenia & 444 & 104 & 23 \\
\hline EU27 & 75439 & 60588 & 78 \\
\hline
\end{tabular}

From Tab. 1 it can be observed that the government of Slovenia spent averagely an annual amount of $444 \mathrm{mln}$ euro in long term period (1995-2013) for investments in building new roads and expending or renewal of existing roads while in 2013 only $104 \mathrm{mln}$ euro were invested. Obviously, the investments in 2013 were significantly below the long-term annual average. For the EU27 countries as a whole, the 2013 investments were about $78 \%$ of the long-term annual investments while for Slovenia they were only $23 \%$. Large decline in investment levels was found in some other CEES such as Czech Republic, Croatia and Hungary. Otherwise, budgets have been fairly increased only in few countries, probably with the aim of stimulating economic growth.

Table2 O\&M expenditures on road infrastructure in CEEC (in 2013) [11]

\begin{tabular}{|c|c|c|c|}
\hline \multirow{2}{*}{ Member State } & $\begin{array}{c}\text { Long-term } \\
\text { average } \\
\text { annual } \\
\text { investments }\end{array}$ & $\begin{array}{c}\text { Investments } \\
\text { in } 2013\end{array}$ & $\begin{array}{c}\text { Ratio of } \\
\text { investments }\end{array}$ \\
\cline { 2 - 4 } & mln euro & mln euro & $\%$ \\
\hline Bulgaria & 131 & 153 & 117 \\
\hline Czech Republic & 744 & 695 & 93 \\
\hline Estonia & 100 & 109 & 109 \\
\hline Croatia & 312 & 319 & 102 \\
\hline Hungary & 897 & 800 & 89 \\
\hline Latvia & 113 & 143 & 127 \\
\hline Lithuania & 207 & 182 & 88 \\
\hline Poland & 605 & 548 & 91 \\
\hline Romania & 1088 & 1059 & 97 \\
\hline Slovakia & 225 & 291 & 129 \\
\hline Slovenia & 184 & 176 & 95 \\
\hline EU27 & 48889 & 42226 & 83 \\
\hline
\end{tabular}

The growth of investments was also reported [11] to be most pronounced between 2001 and 2008. In that period, increasing trend of infrastructure spending was notable particularly in CEEC. From 2008 onwards, expenditures have been significantly reduced due to the impact of the crisis. By 2013, investments decreased under the level at which they were in 1995 . The total annual infrastructure expenditures at the EU level in 2013 were about 105 billion euro, which is below the long-term average level of 130 billion euro [11]. However, after 2011, the stagnation trend and, in some countries, even slightly increasing trend is perceived. The reason for this is in the access to and disbursement of large-scale EU fund. In Slovenia, the crisis had a significant impact on its budget, since road infrastructure perceived a decline of investments of approximately $150 \%$. Besides, the impact of the crisis was reflected in O\&M budgets of many other European countries. Tab. 2 demonstrates the total O\&M expenditures channelled to the road infrastructure among the CEEC countries

Slovenia's O\&M expenditures in 2013 were roughly $5 \%$ below the long-term annual ones, while those in EU27 countries were lower around $17 \%$. According to [12], budget reductions have disproportionately affected local authorities, potentially increasing the gap in the quality between national and local roads. In Slovenia, such expenditures slightly decreased over the period 1999 to 2006 and remained steady from 2006 to 2009. However, in years that followed, they again continued to decline slightly. While crisis almost stopped infrastructure spending since 2008, today needs for improvements of road networks are consequently much more pronounced. In addition, underfunding road maintenance resulted in deteriorated state of many existing roads in Slovenia.

\section{LEGISLATIVE BASIS FOR PUBLIC GOODS IN SLOVENIA}

The general act, which defines Public Goods (PG) in Slovenia, is Law of Property Code (LPC) from 2003 [13]. Here the PG is defined as a good that is in common usage, which means that it can be used by everyone, however in accordance with its purpose and under the same conditions. The term Constructed Public Goods (CPG) is set by certain normative acts, such as: Construction Act [14], Roads Act [15], Waters Act [16], Railway Transport Act [17], and Spatial Planning Act [18].

The construction and interventions on the land and the existing built objects recognized as $\mathrm{CPG}$ represent the maintenance work, which does not require a building permit [14]. According to Construction Act [14], they can be identified as regular maintenance work and maintenance interventions in public interest. This paper focuses on CPG on roads of local interest for which the term local roads can also be used. Processes of construction and interventions on such roads are divided into construction of new roads and maintenance of existing roads. In this regard, the road is defined in Roads Act [15] as the area bounded by the border of "road world" (see Figure 1), which can be used by all participants in traffic or only by certain road users under the conditions provided by law and other regulations. Further, municipality declares the categorization of public roads.

\section{AREAS AND INTERVENTIONS AT ROADS OF LOCAL INTEREST}

Area at a road of local interest is the space in which an object is planned or constructed, and is bounded by buffer zones and $7 \mathrm{~m}$ high air space border [15]. The road area is limited by the boundary of road world. The road world is a land, where boundary is determined by the line between extreme points of the cross section and longitudinal profile 
of the road structure, including elements for drainage such as slopes and ditches $[19,20]$. Buffer zone on the local road is measured outwards from the outside edge of the road world. According to road categorization [15] buffer zone shall be $10 \mathrm{~m}$ for local road, $5 \mathrm{~m}$ for public way and $2 \mathrm{~m}$ for municipal cyclist way. For better explanation, Fig. 1 presents characteristic cross section with areas and boundaries at a road of local interest.

Definitions of construction and interventions on roads representing maintenance works are given in the Roads Act [15] and in the Rules on the construction of IMW and MWPI on public roads [21]. It is necessary to emphasize here that this paper is not focused on regular maintenance work, but on maintenance work, where the capacity and the size of the object can be changed.
Maintenance works on public roads are required to be performed in the manner and under the conditions as set by regulations governing the types of maintenance work and level of routine maintenance. The two methodological frameworks for construction and interventions on local roads are addressed here, i.e. for IMW and MWPI. Both procedures start with activities of gaining relevant initial documents and end with turnover task after completion of maintenance works. Preceding procedures, such as identification of the required land, regulation of the acquisition of land, and the status of CPG are thus not covered within the scope of this article. Therefore, it is assumed that all such procedures are already arranged before beginning of activities in frameworks.

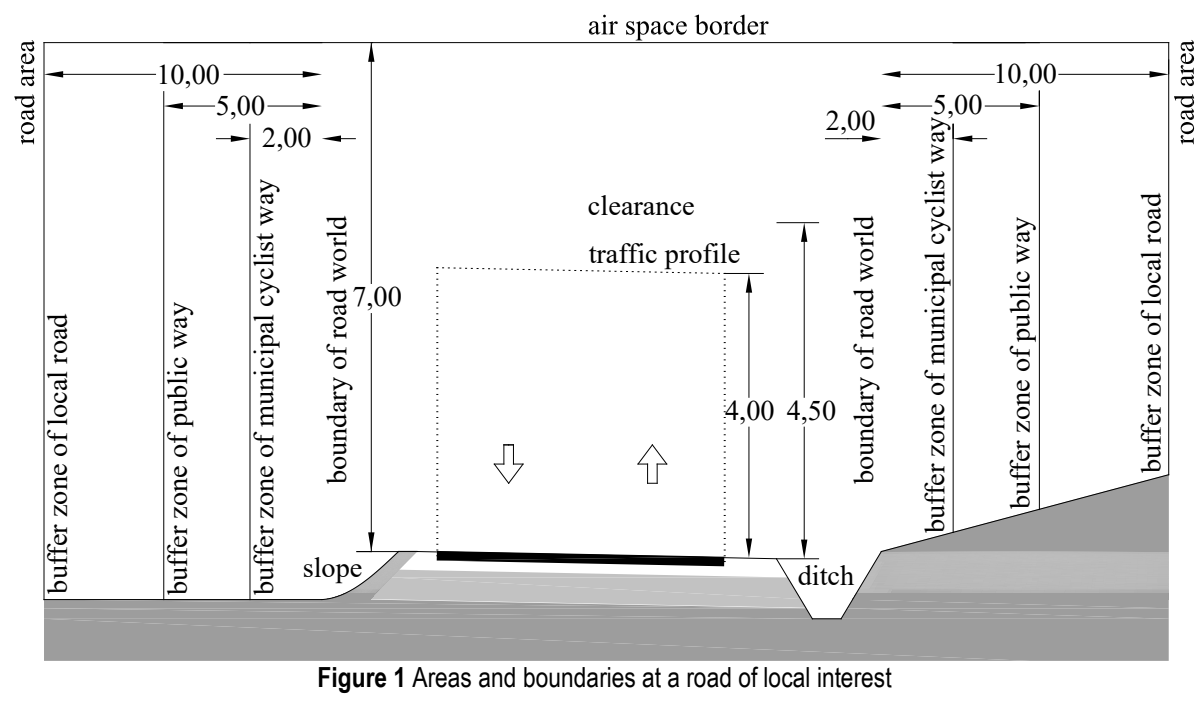

\section{METHODOLOGICAL FRAMEWORK FOR IMW ON LOCAL ROADS}

According to regulations, the IMW are construction works that should not intervene outside the road world. They should not change the capacity of the road, the size of its individual parts, the scope of the installations, appliances and equipment, and other infrastructure in the area of a public road. The implementation of safety improvements of the public road is allowed in the area of maintenance work. Fig. 2 presents the activity diagram for conducting construction and interventions on local roads that should be performed as IMW.

After completed regulation of land ownership and finished review of road world boundaries including dimensions of current road structure, the process of conducting IMW on local roads begins with the preparation of Project Identification. Project Identification represents a systematically organized collection of textual and pictorial materials as well as other necessary texts intended as guidelines for designers to elaborate technical documentation. After reviewing and approving Project Identification, the operator of local road together with the selected designer instructs the elaboration of technical documentation.

The execution of IMW usually bases on Implementation Plan and other relevant documents, such as Safety Plan. Only in exceptional cases, the Detailed Design is elaborated instead of Implementation Plan. The content of Implementation Plan is prepared in accordance with current regulations and scope of planned works. Usual chapters in mentioned plan are: technical report, plans, description of works with quantity take-offs, guidelines, software on systems, and elaborations. Project Conditions and Consents are not mandatorily acquired for the Implementation Plan and its recension is not necessary, either. It is considered that the Implementation Plan is elaborated as soon as it is delivered to the investor.

The next activity is the implementation of bidding procedures for the selection of maintenance contractor, responsible supervisor(s) and coordinator for safety and health at work. If required by legislation [22], a Prior Notice to the Labour Inspectorate must be sent at least 15 days before the start of works on the site. Hence, the decree prescribes that the site must be notified a) when work is scheduled for more than 30 working days and, more than 20 employees working on site at the same time; or b) the scope of the work is 500 persons/days or more. In these cases, Safety Plan must be elaborated. The Site Organization Plan and the site marking with construction board are not mandatory for IMW. However, in any case, it is necessary to regulate road closure before interventions start. A closure should be organized in appropriate way and valid until the completion of all works.

At the beginning of construction, the selected contractor must be introduced into the work. Introduction must be drawn in the Building Diary, and it can be prepared as an independent Minutes. From that event forward, the 
Building Diary must be managed daily and in accordance with the regulations. Furthermore, all other formal Job site administration should be organized for coordination and execution of maintenance works, such as Meeting Minutes, Daily Reports and others. In some cases, Measurement Book must be also managed according to the building regulations or the contract.

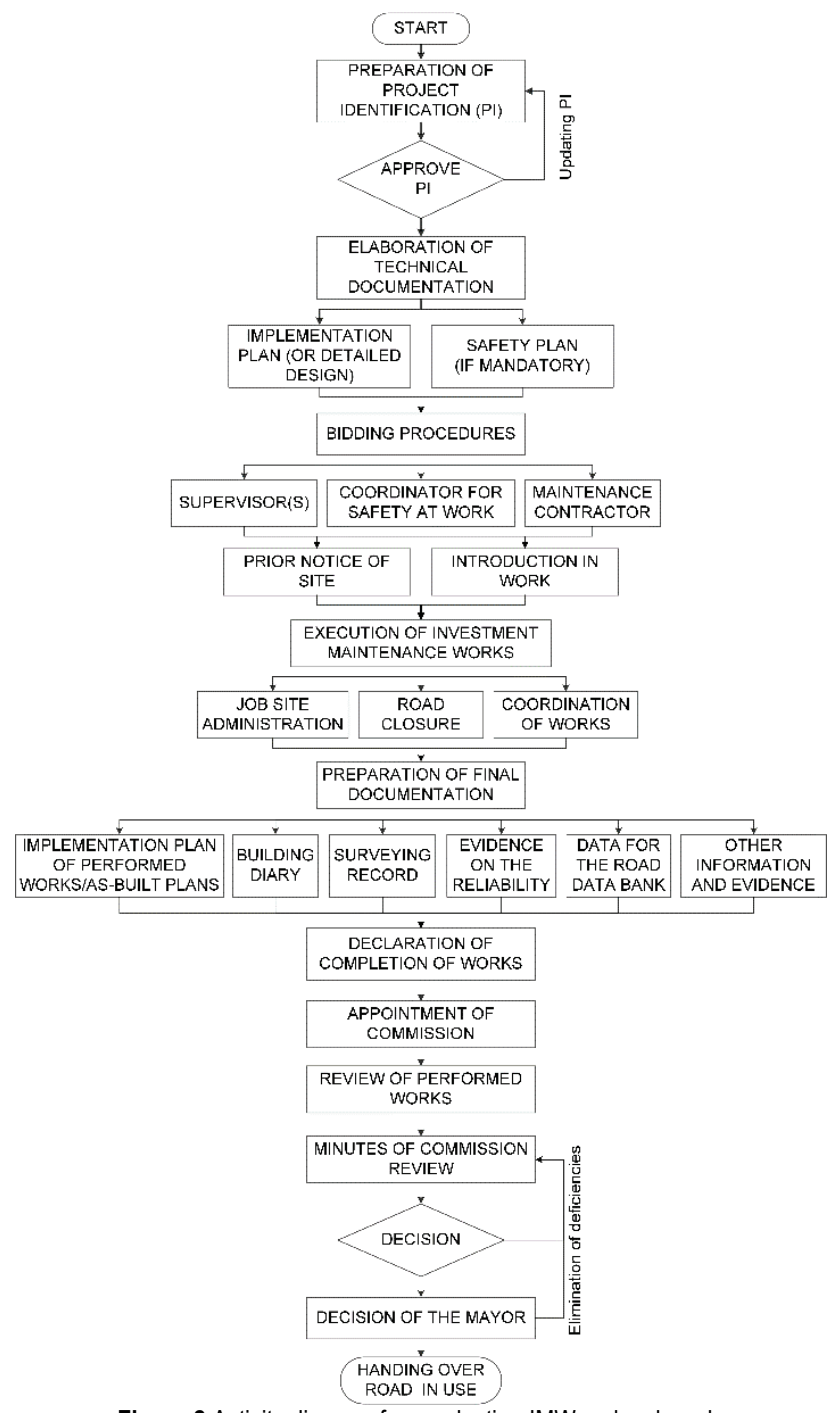

Figure 2 Activity diagram for conducting IMW on local roads

As soon as the performance of work draws to an end, it is necessary to ensure the relevant final technical and other documentation consisting of: a) Implementation Plan of executed works or As-built plans, if works are based on Detailed Design; b) submission of completed Building Diary; c) Surveying Record of the new land situation, d) Evidence on Reliability of the performed works; e) input Data for road data bank; and $\mathrm{f}$ ) other information and evidence, e.g. Warranty, contracts for connection to the distribution system, etc. All documentation is an integral part of the Declaration of Completion of Works, which must be forwarded to the investor within 30 days after the works are finished [21]. Upon receipt of a declaration, investor appoints a Commission for review of performed works. Commission is nominated by the Mayor's decision and consists of site manager(s), responsible supervisor(s), and the representative of local road operator. Review should be performed upon receipt of declaration or after expiry of the 30-day period.

The appointed Commission draws up Minutes about executed review of conducted works, leading to the Commission Decision, which reads as a) identification of deficiencies and request for their elimination; b) proposal for a decision to hand over the road in temporarily limited use till the elimination of deficiencies; c) proposal for a decision to hand over the road in unlimited use. For all these procedures, the provisions of the law are applied, regulating general administrative procedure. Based on Commission Decision, the Mayor issues a decision by which he or she: a) orders to eliminate identified deficiencies; b) orders the temporary limited road use until the elimination of deficiencies; c) issues a decision on handing over a road in unlimited use.

\section{METHODOLOGICAL FRAMEWORK FOR MWPI ON LOCAL ROADS}

MWPI should not intervene outside the road area. These works represent the execution of public road reconstruction, which changes the road capacity, the size of its individual parts, the scope of installations, appliances and equipment and other infrastructure in the public road area. As in the case of IMW, the implementation of improvements related to the safety of the public road is possible, too. When the road area and its boundaries are relatively wide, some MWPI can be implemented without obtaining a building permit, for example: construction of non-complex infrastructural objects, construction of other buildings resulting from the reconstruction plan, and interventions on public infrastructure objects, which must be built or moved due to reconstruction.

Dimension and specificity of non-complex objects are determined in Decree amending the Regulation on classification of construction with regard to their complexity [23]. Within the reconstruction of local public roads, the design may require the execution of variety of accompanying structures, such as: retaining walls, overpasses, aqueducts, noise barriers, and bridges (for maximum span between the supporters $15 \mathrm{~m}$ ). Figure 3 presents activity diagram for conducting construction and interventions on roads that should be performed as MWPI.

The process of conducting MWPI begins after completed regulation of land ownership and review of the boundaries in the road area. The preparation processes in Project Identification are the same as for the IMW. These works typically base on the drawn Detailed Design or in some cases, on Implementation Plan. Detailed Design shall be made in accordance with building regulations. According to the Rules on design documentation [24], the Detailed Design should include the following components: leading folder (information about participants and project), plans (technical report including description of works with quantity take-offs and drawings including technical solutions supported by details), and elaborations (e.g. Safety Plan, if mandatory). It is necessary to obtain a relevant consent from operators of public infrastructure to complete the project documentation. If maintenance works should be carried out for the complex objects, the recension of Detailed Design must be conducted. 


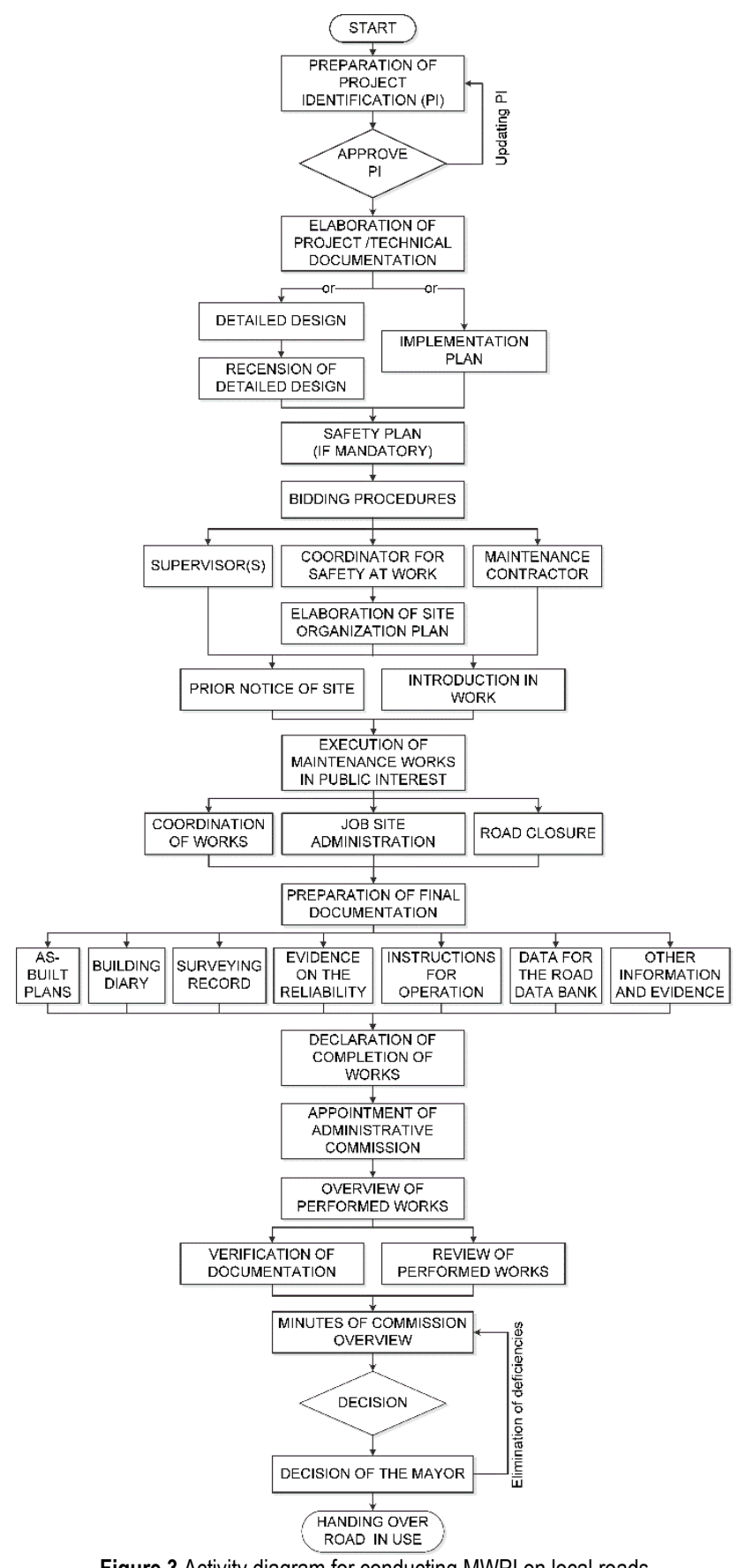

Figure 3 Activity diagram for conducting MWPI on local roads

The next activity for investor is to implement the relevant bidding procedures with the same contractual participants as for the IMW. For the purpose of work organization and preparation, the selected contractor must elaborate a Site Organization Plan, which should be reviewed and approved by the responsible supervisor. Site marking is not mandatory for this type of works. However, mandatory Prior Notice should be sent to the Labour Inspectorate in the same way as for the IMW. At the beginning of site works, the selected contractor must be introduced into the work. Procedures of introduction and all other activities related to the coordination of works, management of the Job site administration, and organization of the road closure are the same as for IMW.

By the end of works, the preparation of the As-built plans and other technical documentation must be ensured. It consists of: a) As-built plans, or in some cases
Implementation Plan of executed works; b) submission of completed and sealed Building Diary; c) Surveying Record of the new land situation, d) Evidence on Reliability of the performed works, e) Instructions for Operation and Maintenance; f) input Data for road data bank; and g) other information and evidence (e.g. warranty). Documentation is an integral part of the Declaration of Completion of Works, which should be forwarded to the investor within 30 days after the work completion [21].

Upon receipt of a declaration, the investor gathers an Administrative Commission for review of the performed works, which is formally appointed by Mayor's decision. Compared to the IMW, process, the one for the MWPI requires a commission that is usually composed of more members and the handing over procedure is expected to be more complex and longer. Thus, Administrative Commission includes at least the following members: president, secretary, police representative and a representative of the local road operator. Other participants, such as other investors (if any) and cofinancers (if any), site manager(s), responsible supervisor(s), construction manager(s) and designer(s) are also invited to attend the overview.

A representative of the concessionaire for regular maintenance and protection of roads as well as the supervisor of the implementation of regular maintenance should be also asked to participate in the work of Administrative Commission. Consequently, the Administrative Commission invites representatives of other operators (state, local community) and representatives responsible for inspecting roads and stewarding. In a similar way as for the IMW, review for the MWPI should be done after the receipt of declaration or after the expiry of the 30-day period.

During the overview, the Administrative Commission first verifies the submission of all required documents (legislative and those set by the contact) and then reviews the performed work on site. Administrative Commission must draw up Minutes about the review and the Mayor issues a decision. Both procedures shall be carried out in the same way as described for the IMW. After obtaining the license for unlimited road use and completing the final statement, which is usually agreed to be done in reasonable time, the entire documentation (i.e. administrative, investment, financial, project and other) should be handed over to the investor.

\section{EXAMPLES OF CONSTRUCTION PROCEDURES}

The applicability of addressed methodological frameworks for IMW and MWPI is supported here by seven different examples. Four examples from a) to d) represent processes for IMW while three examples from e) to g) cover processes for MWPI. The following cases are considered here:

a) Reconstruction of a public road including pavement structure and drainage: existing public way is originally built as a macadam way. Reconstruction works include replacement of unusable buffer rubble, delivery and installation of a new buffer rubble, and implementation of an asphalt roadbase. Drainage works encompass profiling earth ditch, implementation of new catch basin, and construction 
of culverts. Considered works include no change in capacity and no intervention out of the road world.

b) Implementation of new road curbs and asphalt roadbase at urban and local road: the purpose of implementation is to provide appropriate drainage of surface water from the roadway. At the same time, the asphalt roadbase should be replaced. Such measures are ensuring longer durability of the pavement.

c) Replacement of existing asphalt roadbase: existing asphalt roadbase should be removed and replaced with a new one. Unusable buffer rubble of sub-pavement structure needs replacement while sub-structure is in a good condition. The road drainage should be improved by implementing an asphalt gully and a cross-slope.

d) Implementation of a public lighting on local road: the reason for implementation of road lighting is to ensure the safety of pedestrians on local road and to increase illuminance on hazardous road location. The expansion of existing public lighting should be installed and needs its own connection point. Location of installing lighting takes place on the border of the road world so that the investment can be carried out as IMW or MWPI. At this point, the process of IMW is selected.

e) Reconstruction of local roads with new footway and accompanying cyclist way: the implementation of maintenance work in the public interest comprises the enlargement of existing road as well as the construction of cyclist way with accompanying footway and new public lighting. Planned interventions are intended to improve traffic and technical characteristics of local road.

f) Implementation of a retaining wall on a public way in height up to $4 \mathrm{~m}$ : the main purpose of the retaining wall construction is the rehabilitation of the landslide. Planned wall does not affect surrounding of the road area and will help to increase the road safety. Therefore, construction intervention works are considered as other object of reconstruction works and may be implemented as MWPI.

g) Implementation of a new bridge on a local public road: new bridges most commonly represent larger constructions in the context of MWPI on local roads. In this particular example, the construction of a new bridge is intended to replace an existing bridge situated at the same location. More specifically, the planned bridge structure comprises a $12 \mathrm{~m}$ span between supporters and therefore is identified as a non-complex object and can be built as a part of road reconstruction.

For the purpose of better presentation, Tab. 3 demonstrates assigning activities, for each considered example. Activities follow the order of seven project phases: initiation of project, design, bidding procedures, introduction into the work, execution of maintenance works on site, preparation of final documentation and handing over of road in use.

Example a) represents a typical process of conducting IMW that starts with preparation and approval of Project Identification in initiation phase. The elaboration of Implementation Plan follows in the design phase. Next, maintenance contractor and construction supervisor are selected in bidding procurement. Before starting maintenance works on site, the contractor is introduced into work. Arrangement and implementation of road closure must be clearly regulated, too. The Study of road closure is the mandatory part for the works which need elaboration of the Site Organization Plan. During the execution of works, all Job site administration e.g. Building Diary, Measurement Book etc. must be managed daily along with coordination of works.

At the end of execution of works, the final documentation is prepared, consisting of Implementation Plan of performed works, submission of Building Diary, Surveying Record of new land situation, Evidence on Reliability and Data for road data bank. Handing over process of reconstructed road, including the pavement structure and drainage, starts with Declaration of Completion of Works given by contractor. From that event onwards, the investor appoints a Commission and the Mayor decides for review of completed works. The decision for elimination of identified deficiencies is prepared on the inspection Minutes. Thereupon, the same decision is also made by the Mayor. After elimination of all detected deficiencies, road is handed over for unlimited use.

The example b) differs from the example a) in the last phase if the Commission during the review identifies no deficiencies and they decide for direct hand over of road in unlimited use. Procedures required in example c) are identical to those presented in example a). Next, implementation of public lighting in example d) varies from the example a) in design phase, bidding procedures, preparation of final documentation and appointment of Commission for review. Activities in design phase are required here to obtain Project Conditions and Consents and to elaborate Detailed Design instead of Implementation Plan. The bidding procedure requires the selection of electrical installation supervisor. Appliances and equipment are needed here in the scope of documentation preparation for As-built plans and detailed information about electrical wiring. Data for road bank data do not have to be elaborated for this particular example. However, preparation of other important information and evidence is necessary (e.g. details of electrical works, materials and devices; contract for connection to the distribution network, etc.). Last difference, in comparison with the example a), can be found in the composition of Commission for review, where representatives of electro operator and future maintenance of public lighting also participate.

Example e) represents a typical process of conducting MWPI and is also the most comprehensive one. It differs from the example a) in majority of project phases. A design phase is required to elaborate Detailed Design and Safety Plan as well as recension of Detailed Design and to obtain Project Conditions and Consents. In addition, bidding procedure demands the selection of electrical installation supervisor and safety coordinator. Moreover, Site Organization Plan should be prepared for this type of works. Compared to the IMW process phases, Introduction into work includes here the Prior Notice to the Labour Inspectorate and marking the site with a construction board. After the agreed work ends, As-built plans are elaborated as final documentation instead of 
Implementation Plan of performed works. Handing over process differs in members of commission for the final overview. The mentioned commission includes a large number of members and is generally called Administrative Commission. A final review of performed works, generally named Overview, is conducted in two main phases: verification of documents and review on site. Process ends with the completion of all documentation by the investor. Example f) differs from the example e) in supervisor participants because geotechnical supervisor is needed here. Regarding the final documentation, elaboration of Instructions for Operation and Maintenance is required in example f). Finally, the last case of MWPI process application represents the example $g$ ) which varies from the example e) in the part that relates to the supervisor participants where only construction supervision is obligatory.

Table 3 Assigning activities for considered examples in relation to project phases

\begin{tabular}{|c|c|c|c|c|c|c|c|}
\hline \multirow{2}{*}{ Methodology } & \multicolumn{4}{|c|}{ IMW } & \multicolumn{3}{|c|}{ MWPI } \\
\hline & a) & b) & c) & d) & e) & f) & g) \\
\hline \multicolumn{8}{|l|}{ Initiation of project } \\
\hline Preparation and Approval of Project Identification & $\checkmark$ & $\checkmark$ & $\checkmark$ & $\checkmark$ & $\checkmark$ & $\checkmark$ & $\checkmark$ \\
\hline \multicolumn{8}{|l|}{ Design } \\
\hline Elaboration of Implementation Plan & $\checkmark$ & $\checkmark$ & $\checkmark$ & & & & \\
\hline Elaboration of Detailed Design & & & & $\checkmark$ & $\checkmark$ & $\checkmark$ & $\checkmark$ \\
\hline Acquirement of Project Conditions and Consents & & & & $\checkmark$ & $\checkmark$ & $\checkmark$ & $\checkmark$ \\
\hline Recension of Detailed Design & & & & & $\checkmark$ & $\checkmark$ & $\checkmark$ \\
\hline Elaboration of Safety Plan & & & & & $\checkmark$ & $\checkmark$ & $\checkmark$ \\
\hline \multicolumn{8}{|l|}{ Bidding procedures } \\
\hline Bidding procedures for maintenance contractor and supervisor & $\checkmark$ & $\checkmark$ & $\checkmark$ & $\checkmark$ & $\checkmark$ & $\checkmark$ & $\checkmark$ \\
\hline Bidding procedures for selection of geotechnical supervisor & & & & & & $\checkmark$ & \\
\hline Bidding procedures for selection of electr. install. supervisor & & & $\checkmark$ & $\checkmark$ & & & \\
\hline Bidding procedures for selection of safety coordinator & & & & & $\checkmark$ & $\checkmark$ & $\checkmark$ \\
\hline Elaboration of Site Organization Plan & & & & & $\checkmark$ & $\checkmark$ & $\checkmark$ \\
\hline \multicolumn{8}{|l|}{ Introduction into the work } \\
\hline Submission of Prior Notice of site and marking site with board & & & & & $\checkmark$ & $\checkmark$ & $\checkmark$ \\
\hline Introduction of contractor in work on site & $\checkmark$ & $\checkmark$ & $\checkmark$ & $\checkmark$ & $\checkmark$ & $\checkmark$ & $\checkmark$ \\
\hline Arrangement and implementation of road closure & $\checkmark$ & $\checkmark$ & $\checkmark$ & $\checkmark$ & $\checkmark$ & $\checkmark$ & $\checkmark$ \\
\hline \multicolumn{8}{|l|}{ Execution of maintenance works on site } \\
\hline Management of Job site administration & $\checkmark$ & $\checkmark$ & $\checkmark$ & $\checkmark$ & $\checkmark$ & $\checkmark$ & $\checkmark$ \\
\hline Coordination of works & $\checkmark$ & $\checkmark$ & $\checkmark$ & $\checkmark$ & $\checkmark$ & $\checkmark$ & $\checkmark$ \\
\hline \multicolumn{8}{|l|}{$\begin{array}{l}\text { Preparation of final documentation } \\
\end{array}$} \\
\hline Preparation of Implementation Plan of performed works & $\checkmark$ & $\checkmark$ & $\checkmark$ & & & & \\
\hline Elaboration of As-built plans & & & & $\checkmark$ & $\checkmark$ & $\checkmark$ & $\checkmark$ \\
\hline Submission of completed and sealed Building Diary & $\checkmark$ & $\checkmark$ & $\checkmark$ & $\checkmark$ & $\checkmark$ & $\checkmark$ & $\checkmark$ \\
\hline Elaboration of Instructions for Operation and Maintenance & & & & & & $\checkmark$ & \\
\hline Elaboration of Surveying Record and Evidence of Reliability & $\checkmark$ & $\checkmark$ & $\checkmark$ & $\checkmark$ & $\checkmark$ & $\checkmark$ & $\checkmark$ \\
\hline Elaboration of Data for road data bank & $\checkmark$ & $\checkmark$ & $\checkmark$ & & $\checkmark$ & $\checkmark$ & $\checkmark$ \\
\hline Preparation of other information and evidence & & & & $\checkmark$ & & & \\
\hline \multicolumn{8}{|l|}{ Handing over of road in use } \\
\hline Declaration of Completion of Works & $\checkmark$ & $\checkmark$ & $\checkmark$ & $\checkmark$ & $\checkmark$ & $\checkmark$ & $\checkmark$ \\
\hline Appointment of Commission & $\checkmark$ & $\checkmark$ & $\checkmark$ & $\checkmark$ & & & \\
\hline Appointment of Administrative Commission & & & & & $\checkmark$ & $\checkmark$ & $\checkmark$ \\
\hline Review of performed works & $\checkmark$ & $\checkmark$ & $\checkmark$ & $\checkmark$ & & & \\
\hline Overview of performed works and document verification & & & & & $\checkmark$ & $\checkmark$ & $\checkmark$ \\
\hline Preparation of Minutes of Commission Review & $\checkmark$ & $\checkmark$ & $\checkmark$ & $\checkmark$ & & & \\
\hline Preparation of Minutes of Commission Overview & & & & & $\checkmark$ & $\checkmark$ & $\checkmark$ \\
\hline Commission Decision for elimination of deficiencies & $\checkmark$ & & $\checkmark$ & $\checkmark$ & $\checkmark$ & $\checkmark$ & $\checkmark$ \\
\hline Commission Decision for unlimited road use & & $\checkmark$ & & & & & \\
\hline Decision of Mayor for unlimited road use & $\checkmark$ & $\checkmark$ & $\checkmark$ & $\checkmark$ & $\checkmark$ & $\checkmark$ & $\checkmark$ \\
\hline
\end{tabular}

\section{DISCUSSION}

The following discussion focuses on duration, difficulty and clarity of addressed procedures as well as to their influence on overall quality of interventions on roads of local interest. In terms of public goods, current procedures for interventions on local roads in Slovenia are often difficult to be implemented, mostly due to short history of their usage in practice. Namely, issues of public goods in the mentioned field have been more specifically dealt with only in the last 15 years. Thus, to obtain relevant information, which can enable proper execution of interventions, it is necessary to carry out extensive and fragmented search within the building regulations and wider. The procedure can be particularly difficult in the local governments with less qualified personnel and more pronounced financial restrictions. However, at the local level, procedures are frequently implemented more operationally, since they represent real-life problems where the local government must work directly with the participants in projects. 
Concerning the valid legislation for intervention on public roads, the reference regulation [21] provides key definitions and procedures, such as approval of technical/project documentation, supervision and review of performed works. However, current legislation does not clearly define which works can be implemented on land and objects as interventions on public goods; under which procedure they can be executed; and how to define boundaries of interventions. In order to perform procedures correctly, it is necessary to combine various terms, definitions and explanations, which are set in different sections of legislative provisions. At this point, the proposed methodological frameworks give much clearer view on addressed procedures to decision-makers in local governments.

From administrative and legal perspective, CPG procedure is dealt within the regime of public good things, i.e. those, which should be generally accessible to public for common use under equal conditions (e.g. water, sea and seacoast, public roads, public squares, etc.). Legal systems of different countries variously determine the regime of public goods. A narrower scope consists of all facilities that are intended for general use and such regulation can be found, for example, in countries such as Germany [25], Slovenia [26], Croatia [27] and others. The scope of public goods in wider sense is supplemented by movable and immovable property intended for execution of public services. This kind of regulation can be found in France, Belgium and Italy [25] inter alia.

The presented methodological frameworks are intended to contribute to more uniformed construction procedures related to public goods on local roads as well as to give better systematic guidelines for practical implementation of necessary activities. In this way, the increased clarity of required construction procedures is expected to have a positive impact on overall quality of interventions on roads of local interest. Equally, this will facilitate the adoption of correct decisions about procedures and types of activities, necessary documentation, and included participants. Such information can be especially valuable to smaller municipalities that often face a shortage of expert staff from the field of construction.

Systematically and properly applied CPG procedures provide overall quality since interventions in the built environment have to follow the public interest. In the period of construction preparations, this is ensured through the elaboration of technical/design documentation by an authorized engineer, recension of Detailed Design and submission of Prior Notice of site. During maintenance works on site, this is assured by inclusion of supervisors (from different fields) and safety coordinator as well as with incorporation of community representatives or/and road operators including representatives responsible for inspecting roads and stewarding in Administrative Commission.

\section{CONCLUSION}

This paper dealt with the construction procedures for public goods on roads of local interest in Slovenia. At the beginning, a brief overview on expenditures related to road infrastructure was introduced. Afterwards, the legislative basis for public goods in Slovenia as well as the areas and interventions at roads of local interest were addressed. The main part of the paper presented the methodological frameworks for IMW and MWPI on local roads and showed their applicability on several practical examples.

A complete flow of necessary activities was demonstrated to provide usable guidelines for local communities in Slovenia, which can be suitably employed to manage construction procedures from the preparation of project documentation through the realization and inspection all the way to the final acceptance of built objects. Therefore, activity diagrams were developed for both processes and assigned activities were further given in tabular form. Special attention was given to interventions as well as objects of CPG that are allowed within areas of public roads in local interest and do not require a building permit.

Moreover, legislative basis and differences between both aforesaid construction procedures were addressed and supported with seven practical examples. Basic differences found in two processes were related to: i) complexity of elaborating project and other technical documentation; ii) scope of contractor's introduction into the work; iii) preparation of the final documentation; iv) process of final administrative activities in connection with members of commission; v) overview of performed works; and iv) process of handing over of road in use.

The term public goods in Slovenia is quite new and has been in use since 1991 and particularly identified by the Law of Property Code [13] in 2003. A year later, the umbrella law for construction [14] also set the term and procedures for CPG. As regards CPG on public roads, procedures were defined only by Regulation from 2012 [21]. For this reason, CPG has not yet reached a good recognition and wider range of applications in practice. So far, there are not many publicly accessible practices in Slovenia or guidelines, which would systematically address the procedures for CPG on local roads among local or state authorities. On the other hand, Slovenia is currently experiencing a high fragmentation of municipalities and a lack of expert staff in many of them. Therefore, the presented methodological frameworks related to public roads are expected to be a valuable source of information for supporting better quality of land governance at the local level in Slovenia as well as in nearby countries with similar spatial legislation.

Opportunity for easier implementation of the procedures could be provided in the umbrella legislation if it contained explicit sections with definitions of scopes in one place, and if procedures for CPG were set in a similar manner as current procedures for constructions, which require building permits. In this regard, it would be reasonable to give unambiguous definitions, particularly for interventions on land and existing built objects that are most frequently carried out in practice. Moreover, it would be necessary to determine: i) exact criteria by which a correct procedure could be effectively chosen; ii) boundaries of intervention (e.g. as set in Figure 1); and precise content and scope of Implementation Plan.

As a recommendation for future work, it would be interesting to address issues in the context of preceding procedures for $\mathrm{CPG}$ in road areas such as identification of 
required land, regulation of land acquisition, and status of CPG.

\section{Acknowledgements}

The authors acknowledge the financial support from the Slovenian Research Agency (research core funding No. P2-0129).

\section{REFERENCES}

[1] Brezovšek, M. (1990). Local Self-Government in Slovenia: Theoretical and Historical Aspects. University of Ljubljana, Faculty of Social Sciences: Ljubljana, Slovenia.

[2] Grafenauer, B. \& Klarić, M. (2011). Alternative Service Delivery Arrangements at the Municipal Level in Slovenia and Croatia. Lex Localis, 9(1), 67-83. https://doi.org/10.4335/9.1.67-83(2011)

[3] Rouse, P. \& Putterill, M. (2005). Local government amalgamation policy: A highway maintenance evaluation. Management Accounting Research, 16(4), 438-463. https://doi.org/10.1016/j.mar.2005.07.003

[4] Jones, S. \& Walker, R. G. (2007). Explanators of Local Government Distress. Abacus, 43(3), 396-418. https://doi.org/10.1111/j.1467-6281.2007.00238.x

[5] Radović, N., Mirković, K., Šešlija, M., \& Peško, I. (2014) Output and performance based road maintenance contracting - case study Serbia. Tehnički Vjesnik, 21(3), 681-688.

[6] Radović, N., Jokanović, I., Matić, B., \& Šešlija, M. (2016). A measurement of roughness as indicator of road network condition - case study Serbia. Tehnički Vjesnik, 23(3), 881884. https://doi.org/10.17559/TV-20150212204747

[7] Levinson, D., Xie, F., \& Ocel, N. M. (2012). Forecasting and Evaluating Network Growth. Networks and Spatial Economics, 12(2), 239-262. https://doi.org/10.1007/s11067-009-9113-z

[8] Rijavec, V. (2012). Property Issues in the Field of Public Good and Limitations in the Public Interest, with an Emphasis on Water. Geodetski Vestnik, 56(4), 713-724. https://doi.org/10.15292/geodetski-vestnik.2012.04.713-724

[9] Trobiš, J. (2008). The Local Geodetic Service. Lex Localis, $6(4), 489-525$.

[10] Ministry of Infrastructure, Roads. 2017. http://www.di.gov.si/ (05.06.2017).

[11] Schroten, A. \& Hoen, M. (2016). Road taxation and spending in the EU. CE Delft: Delft, Netherlands.

[12] Gleave, S. D. (2014). EU Road surfaces: Economic and safety impact of the lack of regular road maintenance, study. European Parliament, Brussels, Belgium.

[13] Law of Property Code. Official Gazette of the Republic of Slovenia No. 87/02, 91/13.

[14] Construction Act. Official Gazette of the Republic of Slovenia No. 102/04, 126/07, 108/09, 20/11-Decis. CCS, $57 / 12,110 / 13,19 / 15$

[15] Roads Act. Official Gazette of the Republic of Slovenia No. 109/10, 48/12, 36/14-Decis. CCS, 2. Art., 46/15.

[16] Waters Act. Official Gazette of the Republic of Slovenia No. 67/02, 57/08, 57/12, 100/13, 40/14, 56/15.

[17] Railway Transport Act. Official Gazette of the Republic of Slovenia. 99/15.

[18] Spatial Planning Act. Official Gazette of the Republic of Slovenia No. 33/07, 108/09, 80/10, 57/12, 109/12.

[19] Čepelnik, D. (2014). Build public good on local public roads. Diploma thesis, University of Maribor, Faculty of Civil Engineering, Maribor.

[20] Šuman, N., Čepelnik, D., \& Klanšek, U. (2015) Construction of public goods on roads of local interest. Proceedings of the $12^{\text {th }}$ Slovenian Road and Transport Congress, Portorož, Slovenia/Ljubljana, Slovenia.
[21] Regulations on the construction of investment maintenance works and maintenance works in the public interest on public roads. Official Gazette of the Republic of Slovenia No. 7/12.

[22] Decree on the implementation of safety and health requirements at temporary and mobile construction sites. Official Gazette of the Republic of Slovenia No. 83/05, $43 / 11$.

[23] Decree amending the Regulation on classification of construction with regard to their complexity. Official Gazette of the Republic of Slovenia No. 18/13, 24/13, 26/13.

[24] Rules on design documentation. Official Gazette of the Republic of Slovenia No. 55/08.

[25] Virant, M. (2009). Javna uprava. University of Ljubljana, Faculty of Administration, Ljubljana, Slovenia. (in Slovene).

[26] Constitution of the Republic of Slovenia, Official Gazette of the Republic of Slovenia No. 33/99-I.

[27] Jelušić, M. (2009). Public ownership in the legal system of the Republic of Croatia. Split Faculty of Law Journal, 46(1), 151-165.

\section{Contact information:}

Nataša ŠUMAN, PhD, Assistant Professor

University of Maribor

Faculty of Civil Engineering, Transportation Engineering and Architecture

Smetanova ulica 17, 2000 Maribor, Slovenia

natasa.suman@um.si

Zlata DOLAČEK-ALDUK, PhD, Associate Professor

Josip Juraj Strossmayer University of Osijek

Faculty of Civil Engineering Osijek

Vladimira Preloga 3, 31000 Osijek, Croatia

zlatad@gfos.hr

Uroš KLANŠEK, PhD, Associate Professor

(Corresponding author)

University of Maribor

Faculty of Civil Engineering, Transportation Engineering and Architecture

Smetanova ulica 17, 2000 Maribor, Slovenia

uros.klansek@um.si 